\title{
Conflitos, verdades e política no Museu da Escravidão e da Liberdade no Rio de Janeiro
}

Conflicts, truths and politics at the Slavery and Freedom Museum in Rio de Janeiro

\author{
Simone Pondé Vassallo* \\ * Universidade Federal Fluminense - Niterói, RJ, Brasil \\ simonepvassallo@gmail.com \\ https://orcid.org/0000-0003-0773-5141 \\ Luz Stella Rodríguez Cáceres ** \\ ** Universidade Federal do Rio de Janeiro - Rio de Janeiro, RJ, Brasil \\ lunsella@gmail.com \\ https://orcid.org/0000-0002-9452-3907
}




\title{
Resumo
}

Esse artigo se propõe a analisar a tentativa de implementação do Museu da Escravidão e da Liberdade (MEL), marcada por sucessivas dificuldades e cujo intuito é trazer a "verdade" sobre a escravidão. Acreditamos que o MEL se encontre no cerne de intensas disputas políticas mais amplas, daí as adversidades que encontra. Por um lado, ele expressa as dificuldades do movimento negro em trazer a público as memórias da escravidão. Por outro, ele revela os embates entre projetos voltados para ações afirmativas, reparação e reconhecimento no novo contexto político conservador que ocorre tanto na administração pública federal quanto na municipal. Para tanto, nos inspiramos na noção de "rituais abortivos", de Trouillot, para quem as evocações memorialísticas e os pedidos públicos contemporâneos de desculpas por crimes cometidos no passado esvaziam-se do seu potencial político e não possuem um caráter verdadeiramente transformador.

Palavras-chave: museu; escravidão; verdade; política.

\begin{abstract}
This article aims to analyze the attempts to implement the Slavery and Freedom Museum (MEL), overwhelmed by multiple difficulties and whose purpose is to bring the "truth" about slavery. We believe that the MEL is at the heart of intense political disputes, hence the adversities it encounters. On the one hand, it expresses the difficulties of the black movement in bringing the public memories of slavery. On the other, it reveals the tensions between projects based on affirmative action, reparation and recognition in the new conservative political context that occurs in both the federal and municipal public administrations. We are inspired by Trouillot's notion of abortive rituals, for whom memorialistic evocations and contemporary public apologies for crimes committed in the past loose their political potential and lack a truly transformative character.
\end{abstract}

Keywords: museum; slavery; truth; politics. 
Mas centrarmos no passado muitas vezes nos desvia das injustiças atuais para as quais as gerações anteriores apenas lançaram as bases.

Michel-Rolf Trouillot, Silencing the past

"Por um museu sobre a verdade" foi o slogan que acompanhou a campanha publicitária pensada pela Secretaria Municipal de Cultura (SMC) do Rio de Janeiro para divulgar a execução do provisoriamente denominado Museu da Escravidão e Liberdade (MEL), institucionalizado pela administração do prefeito Marcelo Crivella, no início de 2017. Nilcemar Nogueira, diretora da pasta, planeja que as portas do museu se abram em 2020. Seu objetivo é construir um ponto de referência no Brasil e no mundo em estudos e pesquisas relacionados ao resgate e à preservação da memória e da cultura negra e dar visibilidade ao passado do Rio de Janeiro como um dos maiores portos negreiros, partindo do fato recentemente divulgado por pesquisadores de que quase a metade de todos os africanos trazidos como escravos para as Américas vieram para o Brasil, sendo que, dentre estes, uma imensa maioria teria desembarcado pelo Cais do Valongo, no Rio de Janeiro. Reconhecido como Patrimônio Mundial pela Unesco em 2017, o sítio arqueológico Cais do Valongo possui uma dimensão material e imaterial que simboliza a tragédia do tráfico de africanos e sua escravização.

A campanha nacional seria grande. Difundida nas diferentes mídias e redes sociais, contaria com a participação de artistas como Alcione, Xande de Pilares, Tia Surica e Selminha Sorriso, Geraldinho Carneiro, Haroldo Costa. Fotografias dessas personalidades em primeiro plano e em branco e negro estariam acompanhadas do slogan "Por um museu sobre a verdade" somado ao hashtag \#euquerorevelarminhahistória para ratificar a importância do projeto. O pontapé inicial foi dado pela sambista Leci Brandão, conhecida militante negra. A campanha teve uma breve vida que não ressoou e sua rápida morte oferece indícios dos acalorados debates e impasses com os quais o museu se confronta desde que foi anunciada sua criação.

Neste artigo ${ }^{1}$ nos propomos a explorar a trajetória do MEL, marcada por sucessivas dificuldades na sua implementação e cuja campanha publicitária

1 Agradecemos as sugestões de Stefania Capone e os depoimentos de Milton Guran, Ivanir Santos e demais informantes que muito contribuíram para a elaboração deste artigo. 
fracassada pode servir de metáfora. Com o intuito de trazer a "verdade" sobre a escravidão através da sua musealização, a proposta reivindicada para o MEL é a de contribuir para a luta contra a desigualdade racial e pela reparação dos afrodescendentes. Acreditamos que o MEL se encontre no cerne de intensas disputas políticas mais amplas, daí as dificuldades na sua execução. Por um lado, ele expressa as dificuldades do movimento negro em trazer a público as memórias da escravidão. Por outro, ele revela os embates entre projetos voltados para ações afirmativas, reparação e reconhecimento no novo contexto conservador que ocorre com as recentes mudanças na esfera política, tanto no plano federal quanto no municipal. Para tanto, nos inspiramos na noção de "rituais abortivos", de Michel-Rolph Trouillot (2000), para quem as evocações memorialísticas e os pedidos públicos contemporâneos de desculpas por crimes cometidos no passado esvaziam-se do seu potencial político e não possuem um caráter verdadeiramente transformador.

A ideia da verdade se aproxima da retórica do "nunca mais" que tem acompanhado campanhas de reconciliação nacional prometendo revisitar a história para virar a página, para que acontecimentos trágicos nunca mais se repitam, numa clara aproximação da história magistra, ou a história como mestra com uma lição a oferecer. Nos países que viveram longos períodos de ditaduras e que violaram direitos humanos, o tripé "verdade, justiça e reparação" fez parte dos encaminhamentos seguidos para concretizar uma democracia de fato. Objetivava-se resgatar a verdade histórica e aspectos da memória do terrível período nebuloso que terminava oficialmente.

Buscando o "regime de veridição" (Fassin, 2007) do MEL, levantamos as seguintes questões: o que significa um "um museu da verdade"? Que verdade é essa e como pretende ser revelada? O museu em questão será capaz de propor uma nova imagem de nação? Segundo Trouillot (2017), cada narrativa histórica renova um reclamo sobre a verdade. Nesse sentido, haveria uma só verdade sobre a escravidão ou poderiam ser várias?

Este artigo resulta de pesquisa de campo sobre patrimônios afrodescendentes e representações da escravidão na região portuária do Rio de Janeiro realizada desde 2010 pelas duas autoras. O projeto de criação do MEL ainda está em curso e não podemos prever os seus rumos. Nosso recorte temporal vai até agosto de 2018 e optamos aqui por analisar a criação do museu a partir dos efeitos da transição política e suas tensões, tanto no nível federal - com a transferência do 
governo de Dilma Rousseff (PT) para Michel Temer (MDB) - quanto no municipal - com a passagem da prefeitura de Eduardo Paes (MDB) para Marcelo Crivella (PRB). Nossa etnografia se baseia na nossa participação em reuniões, audiências públicas, oficinas promovidas pela da SMC e entrevistas com alguns atores envolvidos, além de acompanhamento de notícias na imprensa.

\section{A musealização da escravidão}

O projeto de criação do MEL deve ser compreendido num contexto mais amplo. A partir dos anos 1990 produz-se uma mudança no regime memorial que se traduz pela criação do que Duffy (2001) chama de museus do sofrimento humano e da luta pelos direitos humanos. Eles são criados em locais que testemunharam genocídios ou situações de cativeiro humano e têm o intuito alertar para a importância da preservação dos direitos humanos. Eles se inspiram no Holocausto judeu, que se internacionaliza como paradigma e influencia o entendimento de outras tragédias humanas e a necessidade de se refletir sobre tais eventos (Huyssen, 2000; Lowenthal, 2009).

Os museus e memoriais sobre a escravidão e o tráfico negreiro também fazem parte dessas recentes iniciativas, responsáveis pela aparição da categoria "memória da escravidão" no espaço público (Chivallon, 2012; Hayden, 1997; Kaufman, 2009). O Projeto Rota do Escravo (RDE), criado pela Unesco em 1994, em Uidá, no Benin, pode ser considerado o ponto de partida dos processos contemporâneos de musealização da escravidão. O programa da Unesco parte da constatação de que a escravidão e o tráfico haviam sido até então omitidos da história da humanidade, sendo preciso romper o silêncio sobre esses temas e considerá-los como acontecimentos centrais à compreensão das sociedades modernas (Chivallon, 2012). Os principais locais de embarque de cativos na costa africana reconhecidos pelo RDE, como o Portal do Não Retorno, no Benin, e a Casa dos Escravos, no Senegal, tornaram-se alvo de visitações turísticas (Ciarcia, 2008) e de peregrinações de lideranças políticas e religiosas, que ali pedem perdão pelo envolvimento pregresso de suas nações no tráfico negreiro (Araujo, 2007, 2014), ainda que essas dinâmicas sejam permeadas por inúmeras tensões (Bruner, 2004). A partir do RDE, tem início um processo planetário de ressurgência memorial da escravidão (Chivallon, 2012). 
Outro marco fundamental foi a Conferência Mundial contra o Racismo, Discriminação Racial, Xenofobia e Intolerância Correlata, promovida em 2001 pela ONU em Durban, na África do Sul. Um dos principais pontos debatidos foi a importância dos países que se beneficiaram da escravidão negra reconhecerem as contribuições culturais, econômicas e científicas dos descendentes de africanos e admitirem a persistência da discriminação racial (Conferência..., 2001). Nessa conferência a ONU reconheceu a escravização e o tráfico transatlântico negreiro como crimes contra a humanidade.

Fassin e Rechtman (2011) apontam para a reconfiguração da economia moral contemporânea, que produz uma transformação do sistema de valores e da relação com a verdade. Nesse novo espaço moral, as noções de trauma, vítima e sofrimento são ressignificadas, ganham centralidade e adquirem uma conotação política, já que estão na base dos pedidos de justiça, reconhecimento e reparação (Fassin; Rechtman, 2011; Lowenthal, 2009; Sarti, 2011). Colocando o dispositivo do museu no âmbito das ações de reparação e reflexão sobre o passado, Walter Hawthorne (Historiadores..., 2017) acredita que a criação de um museu ou um centro de investigação sobre a escravidão é consequência de uma ação corretiva e de um exame da história nos quais se encontra implícito um pedido de desculpas. Nessa nova economia moral, os escravizados são entendidos como vítimas de um intenso sofrimento e os museus da escravidão tornam-se parte do conjunto de atos de reparação. Tais mudanças ocorrem com o fim da Guerra Fria, que desloca as tensões para o eixo Norte-Sul e para o referencial ético dos pedidos de desculpa e de reparação (Chivallon, 2012; Martin; Yaquinto, 2004).

Na Inglaterra, tais ações ocorrem desde os anos 1990. Em Bristol, a municipalidade criou o Circuito do Tráfico Negreiro (Slave Trade Trail) que associa importantes construções históricas, heróis locais e instituições financeiras ao inglório envolvimento passado com o tráfico negreiro (Chivallon, 2001). Em Liverpool, o envolvimento com o tráfico transatlântico negreiro tornou-se público com a criação do Museu Internacional da Escravidão, em 2007 (Smith et al., 2011).

Na França, desde 1998, antilhanos e africanos retiraram o tema da escravidão da invisibilidade e acionaram a recém-criada categoria de "descendentes de escravos". Em 2009, o Museu da Aquitânia, em Bordeaux, criou algumas importantes salas destinadas ao tráfico negreiro e, em 2012, a cidade de Nantes 
inaugurou o Memorial da Abolição da Escravidão. Na Ilha de Guadalupe, território francês no Caribe, foi implantado em 2015 o Centro Caribenho de Expressões e de Memória do Tráfico e da Escravidão. Christine Chivallon se refere a uma economia simbólica da comemoração que se produz no Reino Unido e na França. Assim, "a escravidão sai do seu silêncio e entra no dizível dos rituais públicos" (Chivallon, 2012, p. 37, tradução nossa).

Nos Estados Unidos os debates foram impulsionados pela descoberta acidental de alguns cemitérios de escravos, durante os anos 1990 (Barrett, 2014; Blakey, 2010). O mais importante deles, o African Burial Ground de Nova York, mobilizou inúmeros militantes que, a partir de tensas negociações, conseguiram transformá-lo num Monumento Nacional (Harrington, 1993). Em 2016, foi inaugurado em Washington o Museu Nacional da História e da Cultura Africana Americana, primeiro espaço na capital dos EUA dedicado à história dos afro-americanos, evidenciando o impacto da ação do Estado nessa área.

As iniciativas acima indicam uma mudança na forma de representar a escravidão, que passa a ser publicamente exibida e denunciada, e moralmente condenada. Mas elas também apontam para uma transformação na representação das identidades locais e nacionais. Em Bristol, ocorreu uma alteração no quadro interpretativo da cidade, segundo o qual o seu enriquecimento passa a ser atribuído ao envolvimento com o tráfico negreiro. Já na França, alguns relatos substituem a visão glorificante do passado colonial pela condenação da instituição da escravidão (Chivallon, 2012). Enquanto isso, na África do Sul, o Museu do Apartheid envolve um projeto político mais amplo de nation-building que busca a reconciliação com o passado (Fassin, 2007).

No entanto, alguns autores nos ajudam a colocar esse processo numa perspectiva crítica. François Hartog identifica na centralidade crescente assumida por processos de patrimonialização um "sintoma" de uma nova sensibilidade em relação ao tempo, que se caracteriza por um retrocesso voraz ao passado como objeto de consumo do presente. Segundo Hartog (2013, p. 270), estaríamos vivendo um regime presentista no qual o passado é constantemente atualizado nos termos do presente: "Um presente massivo, invasor, onipresente, que não tem outro horizonte além dele mesmo, fabricando cotidianamente $o$ passado e o futuro do qual ele tem necessidade. Um presente já passado antes de ter completamente chegado." Assim, a patrimonialização seria um sintoma do regime presentista, fruto da crise das grandes utopias e projetos da 
modernidade - a crise da noção de futuro e da concepção finalista da história. Nesse regime, o passado é constantemente atualizado nos termos do presente.

Para compreender o que considera ser um "excesso" de comemorações sobre a escravidão, Christine Chivallon $(2001,2012)$ retoma a noção de presentismo de Hartog, com seu obsessivo desejo de salvaguardar. Para ela, as recentes comemorações da escravidão poderiam falar da incapacidade de verbalizar a lembrança em sua perspectiva de reconciliação e de trabalho de luto em relação à perda fundadora. Teríamos então a passagem de uma "memória insuficiente" para uma "memória em excesso" que paradoxalmente acaba desacreditada pela saturação dos signos, levando consigo o risco de criar um distanciamento em relação à coisa que esses mesmos signos querem representar. Por sua vez, Michel-Rolph Trouillot (2000, p. 131, tradução nossa) também considera que os pedidos de desculpas organizam uma marcação temporal:

Uma novidade central da nossa era é a relação com o tempo histórico. Estamos no umbral de um regime de historicidade que implica uma relação diferente com o passado e especialmente com o futuro. Essa historicidade desafia o direito de definir a Utopia que sempre foi essencial para a legitimidade do Ocidente; poderíamos reconhecer este fato e enfrentar as consequências.

No entanto, para o autor essa nova relação com o tempo histórico traz consequências políticas, e poderíamos nos perguntar se há de fato um novo pacto no presente ou se estamos reciclando sob outro nome as estruturas do passado:

Como eu disse em outro local: "A historicidade da condição humana requer que as práticas de poder e dominação sejam renovadas. É essa renovação que deveria nos interessar mais, mesmo em nome dos nossos passados. Os chamados legados dos horrores passados - escravidão, colonialismo ou Holocausto - só são possíveis por causa dessa renovação. E essa renovação só ocorre no presente. Assim, mesmo em relação ao Passado, nossa autenticidade reside nas lutas do nosso presente." (Trouillot, 2017, p. 151, tradução nossa).

Nessa perspectiva, as reparações coletivas não devem ser acessadas na base de padrões a-históricos de justiça, elas devem ser encaradas como questões políticas. Segundo ele, a responsabilidade histórica não deve se limitar a lamentar 
um pecado original cometido coletivamente, mas considerar as históricas estruturas de privilégio e sua reprodução no presente. As retóricas em torno de sentimentos coletivos de remorso acionadas no interior dos Estados nacionais obscurecem essas relações de poder no imaginário nacional. Radicalizando a sua crítica, Trouillot (2017, p. 185, tradução nossa) considera que caso essas relações de poder não sejam seriamente levadas em conta,

As desculpas coletivas terão pouco poder de transformação. Até o momento, elas nasceram sem a capacidade de encontrar o seu propósito inerente. As fórmulas que elas utilizam para criar os seus sujeitos coletivos [...], apesar de bem-sucedidas ao colocar esses sujeitos em evidência, os impossibilitam de agir. Assim, as desculpas coletivas são fadadas ao insucesso - não por uma possível hipocrisia de alguns atores, mas porque as suas reais condições de emergência negam a possibilidade de uma transformação. Elas são rituais abortivos.

Trouillot e Chivallon partem de situações de "excessos de comemoração" da escravidão que têm como pano de fundo o regime presentista mencionado por Hartog. O presentismo produziria uma ruptura nas formas de comunicação entre presente e passado que, dentro das novas estruturas de poder e dominação, condenaria os rituais comemorativos a um encapsulamento no presente e esvaziaria as representações da escravidão do seu conteúdo verdadeiramente político e transformador.

\section{Antecedentes}

De acordo com Myrian Santos, as representações da escravidão em museus brasileiros se expressam através de algumas possibilidades: pelo seu ocultamento, pela sua exageração (como em referências ao samba e ao futebol), ou ainda através da ampla exposição de objetos e situações de tortura que reproduzem estereótipos de submissão e inferioridade dos negros, neutralizando e naturalizando o terror vivido, com o agravante de silenciar a experiência da escravização. Em todos esses casos se reproduz o imaginário do Brasil como uma "democracia racial" (Santos, 2005). Essa perspectiva começa a ser severamente criticada a partir dos anos 1980 por pesquisadores e pelo movimento negro, que 
enfatizam a agência dos escravizados e condenam a democracia racial como um mito que oculta as relações de dominação racial. Nesse contexto surgem os museus afro-brasileiros de Salvador e de São Paulo, que expõem objetos que valorizam a cultura e a autoestima dos negros, produzindo novas narrativas sobre a nação.

No entanto, nos últimos anos, tal como o que ocorre no plano internacional, um novo paradigma para escravidão emerge no Brasil, fazendo referência às suas implicações traumáticas e gerando pedidos de reparação (Santos, 2015). Um marco dessas novas representações da escravidão ocorre com o desenterramento do sítio arqueológico Cais do Valongo, na região portuária do Rio de Janeiro, no início de 2011. Graças à atuação de pesquisadores, lideranças do movimento negro, representantes do Projeto Rota do Escravo e representantes do poder público, o cais é exibido como o local por onde mais teriam desembarcado africanos escravizados em todo o mundo (Vassallo; Cicalo, 2015), tendo funcionado nas primeiras décadas do século XIX. Nas principais narrativas a respeito do cais, ele é representado como o maior símbolo do tráfico transatlântico negreiro fora da África e conduz à denúncia de que o Brasil e o Rio de Janeiro foram, respectivamente, o maior país e a maior cidade escravagista do mundo. ${ }^{2}$ Graças a esse simbolismo que passa a encarnar, o Cais do Valongo é reconhecido em julho de 2017 como patrimônio da humanidade pela Unesco na categoria sítio de memória sensível. Juntamente com Hiroshima, Auschwitz e campos de concentração na Polônia, eles remetem a locais que testemunharam grandes tragédias e crimes contra a humanidade e, por todo o sofrimento que representam, não deveriam jamais ser esquecidos.

O desenterramento do cais deu origem ao Circuito Histórico e Arqueológico de Celebração da Herança Africana na Zona Portuária, atendendo a demandas do movimento negro de reconhecimento dessa localidade como um território negro também conhecido como "Pequena África" (Guimarães, 2016; Vassallo, 2015). Ao dar ampla visibilidade para as memórias da escravidão, essas iniciativas contribuíram fortemente para os pedidos de reparação elaborados por alguns setores do movimento negro, conferindo-lhes visibilidade e força

2 O Brasil teria recebido cerca de 4,68 milhões de africanos escravizados e, desses, mais de 2 milhões teriam desembarcado no Rio de Janeiro, sendo mais de 500 mil pelo Cais do Valongo. 
política. ${ }^{3}$ Elas se somam às políticas de ação afirmativa que ocorrem no país sobretudo a partir dos anos 2000.

Tanto o desenterramento do cais quanto a elaboração do circuito aconteceram durante a dupla gestão do prefeito Eduardo Paes (2009-2016, do MDB), responsável pelo ambicioso projeto Porto Maravilha de revitalização da região portuária, com o intuito de adequar a cidade aos grandes eventos que estaria recebendo, como a Copa do Mundo de Futebol (2012) e os Jogos Olímpicos (2016). A exposição do Cais do Valongo e dos pontos que integram o circuito nunca foi prioridade da administração de Paes, mas foi acatada por atender aos anseios do prefeito de valorização imobiliária de uma região até então considerada estigmatizada. Com esse intuito, Paes também apoiou a sua candidatura junto à Unesco, visando a promoção do bairro através do turismo. Essa iniciativa contou com a forte participação de órgãos públicos municipais, como o Instituto Rio Patrimônio da Humanidade (IRPH - antiga Subsecretaria de Patrimônio), a Companhia de Desenvolvimento Urbano da Região Portuária (CDURP) ${ }^{4}$ e o setor de relações internacionais da prefeitura. Também contou com o apoio de órgãos municipais voltados para a promoção da igualdade racial, como o Comdedine e a Ceppir, de lideranças do movimento negro, de lideranças de religiões de matriz africana e da cultura afro-brasileira, e de pesquisadores universitários dedicados a questões afrodescendentes (Vassallo; Cicalo, 2015).

Num contexto até então de fortalecimento das políticas de ação afirmativa e de valorização do patrimônio afrodescendente, ainda na gestão da presidenta Dilma Rousseff, o pedido de reconhecimento do Cais do Valongo pela Unesco também obteve forte apoio de órgãos federais, como o Ministério da Cultura, o Iphan, a Fundação Palmares e a Secretaria Nacional de Promoção de Políticas de Igualdade Racial (Seppir). Através de uma convergência de interesses de órgãos do governo federal e municipal, e com o apoio de expressivos setores da sociedade civil, a candidatura do cais foi elaborada e aceita num brevíssimo espaço de tempo, ainda que permeada por intensos conflitos (Vassallo; Cicalo, 2015). O Iphan foi o órgão responsável pelo encaminhamento do dossiê de candidatura.

3 Ver, por exemplo, o Relatório parcial da Comissão Estadual da Verdade da Escravidão Negra no Brasil (2015) e o projeto de lei municipal n. 774/2018 (Rio de Janeiro, 2018), de delimitação territorial da Pequena África no Rio de Janeiro como reparação pelos crimes da escravidão.

4 Companhia criada através de parceria público-privada para gerir o projeto de revitalização. 
Dentre os compromissos firmados pelo Iphan junto à Unesco e ratificados pela prefeitura consta a criação de um Memorial da Diáspora Africana localizado bem em frente ao cais, no prédio das Docas D. Pedro II. A equipe responsável pelo dossiê de candidatura do cais, tendo à frente o antropólogo Milton Guran, entendia que seria preciso um grande museu sobre a diáspora africana para melhor elaborar a narrativa que se desejava conferir ao cais. Além disso, o memorial teria um papel político. De acordo com Guran, o reconhecimento do cais pela Unesco, acrescido do memorial, atuaria como "uma enorme alavanca a nível do debate sobre as diásporas em toda a América", 5 outorgando protagonismo ao Brasil nesse debate; o governo federal seria o grande mentor desse projeto, sendo o Iphan o órgão responsável pela sua realização, pois "cabe ao governo federal a relação com os demais estados e com o mundo, com a diáspora, com as Américas". Além disso, o memorial era também uma antiga demanda do movimento negro, que se intensificou com o desenterramento do cais.

O Cais do Valongo e o Memorial da Diáspora Africana trariam consigo um novo imaginário e um novo projeto para a nação brasileira, que por muito tempo repousou no ideário de uma "democracia racial". Para Guran, essa é "a mais importante atitude do governo brasileiro frente à sua matriz africana no plano internacional. O Estado brasileiro assumiu de fato que é uma nação que deve à sua constituição a entrada de 4 milhões de africanos escravizados". Por isso, segundo ele, "a candidatura do cais foi tratada como um projeto do Estado brasileiro".

No entanto, as recentes e profundas mudanças políticas ocorridas tanto no governo federal quanto no municipal repercutiram no simbolismo emanado pelo cais, impactaram na construção do memorial e redirecionaram o projeto de nação que se delineava. Em janeiro de 2017, Marcelo Crivella assume a prefeitura do Rio de Janeiro pelo PRB, partido formado majoritariamente por neopentecostais, cuja ascensão expressa a "onda conservadora" que atravessa o Brasil. ${ }^{6}$

5 Esta e as demais citações de Milton Guran são de entrevista concedida em outubro de 2017.

6 As igrejas neopentecostais e a chamada "bancada evangélica" por elas constituída têm se caracterizado pela defesa do mérito e do empreendedorismo individual, condenação moral das políticas redistributivas, menor presença do Estado na economia, terceirização da força de trabalho, mais regulação jurídica da moralidade pública. Também vêm apoiando a chamada "bancada ruralista" em oposição aos que militam pelo direito à terra indígena e quilombola (Almeida, 2017a). 
Sobrinho do bispo Edir Macedo, ${ }^{7}$ Crivella é bispo licenciado da Igreja Universal do Reino de Deus (Iurd), denominação conhecida pelas suas ações de intolerância às religiões de matriz africana. Através de acordos políticos, ele nomeia como sua secretária de Cultura a empreendedora cultural Nilcemar Nogueira, ${ }^{8}$ militante negra, neta de criação do compositor Cartola, ligada ao mundo do samba, da favela e das religiões de matriz africana. Com a mudança de administração, é Nilcemar quem assume, como um projeto pessoal, a criação do museu bem em frente ao Cais do Valongo. No entanto, ela o faz ao seu próprio modo, rompendo com o projeto anterior e com os atores a ele vinculados. Em vez de um museu gerido pelo governo federal, através do Iphan, tal como seria o memorial sugerido pelos elaboradores do dossiê de candidatura do Cais do Valongo para a Unesco, ela propõe um museu municipal, tendo a Secretaria de Cultura como seu principal órgão responsável. Por sua vez, essa mudança implicou uma substituição do nome: não mais Memorial da Diáspora Africana, mas sim Museu da Escravidão e da Liberdade (MEL). Com esse gesto, o conflito direto entre Nilcemar Nogueira e os defensores do antigo projeto ficou enunciado.

Em nível federal, a chegada de Michel Temer à presidência da República, em meados de 2016, também impacta os rumos do museu. ${ }^{9}$ Apesar do compromisso assumido junto à Unesco, a nova direção do Iphan concorda em transferir a responsabilidade da criação do MEL para a Secretaria Municipal de Cultura, desincumbindo o governo federal dessa tarefa.

Portanto, o projeto de criação do MEL só pode ser compreendido no cerne de uma disputa política mais ampla que envolve as contendas entre a gestão municipal de Paes e de Crivella, e que também encontra eco nas mudanças na gestão federal após o golpe jurídico-parlamentar contra Dilma Rousseff. Todas essas discrepâncias, por sua vez, encerram conflitos que falam de diferentes (e divergentes)

7 Fundador da Igreja Universal do Reino de Deus (Iurd).

8 Foi diretora de Carnaval da Estação Primeira da Mangueira e presidente do Museu da Imagem e do Som. Cofundou o Centro Cultural Cartola e criou o Museu do Samba em 2015, como parte da sua iniciativa para a inscrição do samba carioca na lista do Iphan do patrimônio cultural imaterial brasileiro.

9 Vale lembrar que Temer (MDB) assumiu a presidência da República em meados de 2016 através de um processo de impeachment de Dilma Rousseff (PT) por muitos qualificado como um "golpe", em cuja votação parte significativa dos deputados mobilizou léxicos como "deus", "família" e "nação" em detrimento de "democracia", "estado de direito" e "cidadania” (Almeida, 2017b). 
projetos de nação. Opondo-se às tradicionais representações do Brasil como uma "democracia racial", o Cais do Valongo emerge invertendo essa equação que implica o reconhecimento do Brasil como o maior país escravagista do mundo, num contexto em que a escravidão é reconhecida pela ONU como um crime contra a humanidade. $\mathrm{O}$ cais também proporciona argumentos que fortalecem as políticas de ação afirmativa e demandas de reparação feitas pelos movimentos negros. No entanto, o projeto e a mensagem do cais e do museu parecem estar sendo silenciados nas novas gestões tanto no plano federal quanto no municipal.

\section{O MEL}

Logo que assumiu a pasta, a Secretária de Cultura manifestou publicamente o seu desejo de criar o museu. O prefeito recém-empossado acatou o pedido e promulgou o decreto $\mathrm{n}^{\circ} 43.128$, de 12 de maio de 2017, que lhe dá origem (Rio de Janeiro, 2017). Na primeira reunião pública de apresentação do projeto do MEL à sociedade civil, em 21 de março de 2017, Nilcemar Nogueira nos revela o seu alinhamento com os debates internacionais que entrelaçam as memórias públicas da escravidão à luta contra a desigualdade racial:

Construir um Museu da Escravidão e da Liberdade no Rio de Janeiro consiste na oportunidade de celebrar um Brasil culturalmente rico, valorizando as conquistas do povo negro e as contribuições da cultura de matriz africana, e de se refletir profundamente sobre as influências de nosso passado escravocrata na situação de exclusão social na qual ainda vive boa parte dos afro-brasileiros e no latente racismo que prevalece em nossa e outras sociedades. (Museu..., 2017).

Em seguida, o fato de o Brasil e o Rio de Janeiro terem sido os maiores portos de desembarque de escravizados - chegados sobretudo pelo Cais do Valongo - é apontado como uma das principais justificativas para a criação do museu. Por fim, Nilcemar declara que "no século XXI, o MEL será alimento para a fome de informação, de memória, de reparação e de liberdade". Com isso, a secretária de Cultura expõe os eixos norteadores do seu projeto que se diz ser acima de tudo político, já que giraria em torno da luta contra a discriminação e a desigualdade racial e envolveria direito à memória e reparação. 
Como apontamos, a noção de "verdade" tem sido central no projeto de Nilcemar Nogueira (2017), que assim o justifica: "Tenho lacunas de conhecimento que não quero que meu neto tenha. Minha consciência racial e minha militância nasceram da compreensão de nossa história. Isso passa por não esconder o que foi a escravidão." Em outras ocasiões ela tem afirmado que a condição para aceitar a pasta foi a de ter carta branca do prefeito para levar a cabo um museu que se propõe a "tratar o legado da escravidão sob a ótica da verdade e da reconciliação, consolidado coletivamente, com participação da sociedade civil" (grifo nosso). ${ }^{10}$

O MEL é apresentado com a premissa de ser uma construção coletiva, de baixo para cima, que dará visibilidade à presença e participação dos negros na cidade do Rio de Janeiro, onde cada uma das decisões que lhes concerne será tomada seguindo a escuta atenta dos atores interessados. Para levar a cabo essas premissas, Nilcemar e alguns membros da sua equipe visitaram os museus da escravidão de Liverpool e da Ilha de Guadalupe, bem como o Museu Nacional da História e da Cultura Africana Americana de Washington, e em seguida convidaram alguns de seus representantes para um seminário sobre o MEL, no Rio de Janeiro. ${ }^{11}$

Um grupo de trabalho foi criado para apoiar o desenvolvimento do museu, que no início contou com representantes de diversas instituições do município ${ }^{12}$ e com membros de movimentos sociais e culturais da região portuária. Este se dividiu em três subgrupos: 1) Território Sociocultural, direcionado para o mapeamento e levantamento dos atores da região portuária; 2) Território Físico, voltado para o levantamento das condições físicas e materiais dos bairros adjacentes e do próprio prédio; 3) Acervos, encarregado de mapear a existência de acervos digitais, documentais, arqueológicos e museológicos

10 Em discurso oferecido na audiência pública "Área portuária, Pequena África e políticas culturais", Câmara Municipal do Rio de Janeiro, 11 de agosto de 2017.

11 Seminário "Por um museu sobre a verdade", ocorrido no Centro Cultural José Bonifácio, em 20 de setembro de 2017.

12 Secretaria Municipal de Cultura, Secretaria Municipal de Urbanismo, Infraestrutura Habitação/ Riourbe, Instituto Rio Patrimônio da Humanidade (IRPH), Instituto Pereira Passos (IPP), Companhia de Desenvolvimento Urbano da Região do Porto do Rio de Janeiro (CDURP), Procuradoria-Geral do Município, Arquivo Geral da Cidade do Rio de Janeiro, Iplan Rio. 
relacionados ao tema da escravidão nas diversas secretarias e/ou órgãos da administração pública.

A partir da constituição desses subgrupos de trabalho, uma série de oficinas aconteceu ao longo de 2017 com o intuito de consultar os interessados sobre o museu, o conteúdo e a forma com que gostariam de ser representados os afrodescendentes e sujeitos com trajetórias ligadas à região portuária. O subgrupo Território Sociocultural, por exemplo, iniciou um mapeamento de atores sociais relacionados à cultura afro-brasileira atuantes nessa área da cidade do Rio de Janeiro. Esse mapeamento pretendeu ser complementado por meio das informações que seriam coletadas em um formulário on-line, no qual os interessados deveriam se inscrever e preencher nome, contato, endereço e responder a perguntas como: "Qual sua relação com a cultura afro-brasileira?”; "Se você fosse sugerir outro nome para o museu, qual seria?"; "Que temas você considera relevantes para as exposições e os programas a serem oferecidos pelo museu?"; "Que temas você encontra como relevantes para o museu?" A ideia do formulário não chegou a se concretizar porque o link saia sistematicamente do ar e pela total incapacidade de despertar o interesse das pessoas no projeto.

Para alguns atores, esse mecanismo de participação não seria mais que uma forma de legitimar decisões já tomadas e de ignorar os pedidos de acadêmicos e parte do movimento negro de que o museu fosse de competência nacional, dada a sua importância. Para outros, tratava-se de uma proposta vazia. Em conversa informal, Mãe Celina, do Centro Cultural Pequena África, lamentava a falta de decisões concretas a partir das reuniões e confessava exaltada: "Nos trouxeram para opinar sobre uma proposta que jamais tem sido apresentada, $\mathrm{e}$ é a gente que tem que dar os insumos, mas não saímos do mesmo circulo."

Ao cabo de um ano de reuniões e seminários, a única coisa que estava clara era que o MEL seria um museu de território, ${ }^{13}$ o que significava abrigar os pontos que inicialmente compuseram o Circuito Histórico e Arqueológico de Celebração da Herança Africana, acrescidos de alguns outros, e perder de vista a dimensão nacional e transnacional. Contudo, se pudermos resumir o primeiro

13 O museu de território é definido pelas gestoras como um museu cujas coleções são representativas de um território específico, mais ou menos vasto e cuja ligação com esse mesmo território se concretiza através de um conjunto de ações em articulação com a comunidade e outras instituições locais. 
ano de gestão do MEL, só poderíamos apontar as boas intenções da sua idealizadora, mas o projeto em si não conseguiu avançar. Até agosto de $2018{ }^{14}$ os participantes das reuniões continuavam sem saber qual seria a "verdade" que o museu se propunha a desvelar, qual história do negro se queria exaltar, ou de que forma as memórias da diáspora seriam resgatadas e expostas. Durante o seminário "Por um museu sobre a verdade", ${ }_{15}^{15}$ que compunha uma dessas reuniões, o ex-ministro da Igualdade Racial, Edson Santos, manifestou que ainda que o museu fosse um ponto de convergência, a participação sem resultados estava esgotando os ânimos dos interessados, e instigou a secretária com a seguinte frase: "Nos ouça, mas decida", ecoando assim os anseios dos participantes, que seguiam sem conhecer o plano museológico. Para alguns protagonistas, esses encontros foram adquirindo um caráter de blindagem política para a secretária, que se viu fragilizada, sem maior respaldo político na administração municipal ou na Câmara de Vereadores e alvo de críticas dos movimentos sociais não apenas pelo museu não sair do papel, mas também pela própria gestão do setor cultural, que se viu asfixiado tanto pelas políticas conservadoras como pelos contingenciamentos econômicos realizados pelo prefeito Crivella, que atingiram em cheio as iniciativas culturais afro-brasileiras.

Apesar de Nilcemar Nogueira afirmar repetidamente que a sua condição para assumir a pasta foi a de ter plena liberdade para realizar os projetos que desejasse, ela também declarou que a construção do MEL se daria através de captação de recursos da iniciativa privada, sobretudo através da Lei Rouanet de incentivo à cultura, e que já haveria uma empresa chinesa interessada. ${ }^{16}$ Um convênio teria sido assinado com a Unesco em 20 de novembro de 2017, em que esta administraria captações e faria as licitações para os contratos necessários. Por parte de bancos e organizadores internacionais, a SMC contava em janeiro de $2018 \mathrm{com}$ R\$ 10 milhões em doações para o projeto (Reis; Autran, 2018). Em contrapartida, a destinação orçamentária do prefeito Crivella para o museu em 2018 seria

14 Até agosto de 2018 a SMC divulgou ter realizado 80 reuniões com mais de 200 entidades, envolvendo a escuta de mais de mil pessoas, assim como teria efetuado 50 apresentações e discursos proferidos sobre o MEL.

15 Realizado em 25 de novembro de 2017 no Museu do Amanhã.

16 Informação veiculada durante o seminário "Por um museu sobre a verdade", em 25 de novembro de 2017. 
de $\mathrm{R} \$$ 1.000,00, tal como o noticiou o jornalista Ancelmo Gois (2018). Vale lembrar que no início do mandato, no ato solene de apresentação da secretária de Cultura, Crivella anunciava que Nilcemar Nogueira teria que "fazer mais com menos", reforçando o exercício de austeridade que marcaria seu mandato. Tal fato nos leva a perguntar em que consiste o "apoio" da prefeitura e a sua "carta branca", que não se traduzem em repasse de verba para a execução do projeto.

As sucessivas reuniões de discussão do museu giraram em círculos com debates repetitivos que não saíam do lugar. A explicação para essa situação vai além da falta de repasse financeiro por parte da prefeitura e nos mostra o quanto Nilcemar Nogueira, com seu projeto de criação do MEL, estaria isolada no novo cenário político. Seu insulamento expressa tanto as tensões dentro do próprio movimento negro quanto os embates mais amplos que refletem a fragilidade de um projeto particularmente político que, ao subverter os pressupostos tradicionais de representação da nação, parece não despertar mais interesse dos novos representantes dos setores do Estado que deveriam assumi-lo.

\section{As controvérsias}

Desde seu anuncio, o MEL tem estado envolto em diversas divergências. A primeira se refere ao nome escolhido. Ainda que para muitos a reflexão sobre a escravidão seja impostergável, o nome dado ao museu foi alvo de acirradas críticas por parte de diversos setores do movimento negro. A sigla MEL foi proposta por sua alusão intencional ao mel de engenho derivado da cana-de-açúcar, essencial na alimentação dos escravos no Brasil colonial:

Altamente nutritivo, o mel de engenho tinha vital importância na senzala como fonte de carboidratos e ferro capaz de garantir aos escravos energia necessária para os pesados trabalhos nas fazendas de açúcar. $\mathrm{O}$ alimento adoçava a vida puro, misturado à farinha, com mandioca, cará ou inhame, acompanhado de pão ou de queijo e de tantas outras formas. (Museu..., 2017).

Tal associação foi suficiente para uma parcela de intelectuais e historiadores negros acusarem o projeto de edulcorar uma instituição tão perversa como a escravidão. Para o compositor e escritor negro Nei Lopes (2017), 
como chamar de MEL a exposição permanente de um holocausto que, iniciado sob o pretexto da evangelização exatamente dos "gentios" e estendendo-se por mais de quatro séculos, custou à África milhões de vidas humanas, animais e vegetais, numa catástrofe ecológica sem precedentes, que repercute até hoje?

Na defesa do projeto, a secretária de Cultura recuou do nome e daí em diante o MEL vem sendo apresentado como um nome provisório, até que um novo nome venha a ser definido mediante votação. ${ }^{17}$

Além disso, temos os defensores do Memorial da Diáspora Africana, que envolvem os pesquisadores e técnicos responsáveis pela elaboração do dossiê do Cais do Valongo, setores do movimento negro e integrantes da administração de Paes, no município, e de Dilma Rousseff, no governo federal. Existem ainda outros projetos de museus relacionados à cultura afro-brasileira na região: um elaborado por pesquisadores do Instituto de Pesquisa e Planejamento Regional da UFRJ (Ippur), outro por integrantes da ONG Ação da Cidadania e um terceiro por alguns militantes negros com apoio do governo estadual, mas nenhum deles saiu do papel. Há ainda o projeto de lei municipal n. 774/2018 (Rio de Janeiro, 2018), fruto da iniciativa de algumas lideranças do movimento negro que são contra a construção de um museu e optam pela criação do que chamam de "memorial vivo", que consiste na delimitação e restauração do território da Pequena África. Assim, a desavença em torno do nome expressa as tensões entre os diversos interesses em torno do projeto do museu.

A divergência em torno do nome também expõe questões mais profundas. Ela atualiza uma oposição central e constitutiva do campo da cultura afro-brasileira, que confronta dois distintos mitos de origem: de um lado, o que defende que a instituição da escravidão foi de tal modo devastadora que é somente a partir dela que a cultura negra pode se erigir. De outro, o que celebra a África e a herança africana como matrizes culturais. Ao longo do século XX, há um tensionamento dessas duas perspectivas que atravessa a prática cultural, a academia

17 Durante o seminário de 25 de novembro no Museu do Amanhã, houve uma votação sobre os possíveis nomes para o nome do novo museu. Os três mais votados foram: "Museu da História e da Cultura Afro-brasileira" (39,7\%), "Museu da Escravidão e da Liberdade" (35,9\%) e "Museu Histórico Afro-brasileiro" (9,6\%). O nome será definido em votação aberta no site da Secretaria Municipal de Cultura. Dentre as opções, o nome de "Museu Nacional do Valongo - Memorial da Diáspora Africana" não foi sequer mencionado. 
e a militância negra e gera acirrados debates (Santos, 2015). Noções como raça, cultura e mestiçagem são acionadas e põem em jogo tanto representações dos negros quanto da nação brasileira. Na contemporaneidade, o nefasto legado da escravidão volta à cena como um trauma histórico a ser superado e serve de base aos pedidos de reparação. Mas o seu reexame não oculta as dificuldades de se lidar com as representações tão negativas que engendra, daí a intensa oposição que o projeto do MEL desperta em muitos militantes negros. Para além dos interesses mais imediatos, a disputa entre o Museu da Diáspora Africana e o MEL deve ser entendida à luz dos embates entre as narrativas que privilegiam a África ou a escravidão, muito bem expressas nas palavras de Nei Lopes, para quem a escravidão deveria ser lembrada apenas

por ter legado ao Brasil e ao mundo um inestimável patrimônio cultural, expresso em novas e instigantes formas de pensar, agir, trabalhar, criar, produzir, viver enfim. Em vez de um museu da escravidão, muito melhor seria projetar um museu da herança africana. (cf. Lisboa, 2017).

Um outro conflito ameaça o projeto de criação do museu. Trata-se do confronto que envolve o próprio espaço onde o MEL deverá ser construído. A localização do museu está prevista para acontecer no Galpão Docas Pedro II, uma construção monumental de 6500 metros quadrados situada imediatamente em frente ao Cais do Valongo. Além da localização estratégica, o prédio foi investido de um grande simbolismo que, para os seus defensores, justifica a construção do museu. Para estes, a importância do prédio reside no fato dele ter sido projetado em 1871 pelos irmãos André e Antônio Rebouças, dois engenheiros negros que teriam recusado a mão de obra escrava na sua construção. Com isso, o prédio já teria uma origem relacionada à contribuição dos afrodescendentes à civilização brasileira e à sua luta contra a escravidão.

No entanto, há 18 anos o Galpão Docas Pedro II é a sede da Ação da Cidadania, ONG de referência central para os movimentos sociais brasileiros. Ela foi fundada pelo sociólogo e ativista de direitos humanos Herbert de Souza, conhecido como Betinho pelo seu importante programa de combate à fome. Com a sua morte, a ONG passou a ser administrada por seu filho, Daniel de Souza. O prédio é de usufruto do Ministério Público Federal, mas foi cedido à ONG através de acordo envolvendo a própria União. 
Durante a elaboração do dossiê de candidatura do Cais do Valongo, ainda na gestão de Dilma Rousseff na presidência da República, houve um consenso entre a então presidenta do Iphan, Jurema Machado, setores da municipalidade da gestão de Eduardo Paes, a equipe de elaboração do dossiê e militantes do movimento negro em torno da importância da criação do memorial no prédio das Docas Pedro II e da necessidade de a ONG desocupar o espaço. Jurema Machado negociou com a Superintendência de Patrimônio da União para que o Iphan obtivesse o usufruto do prédio e ali construísse o museu. Mas, de acordo com Milton Guran,

o Ministério Público fez várias reuniões e se comprometeu a abrir mão do usufruto em nome do Iphan. Quando essa reunião seria formalizada, ou seja, o Iphan receberia da SPU o usufruto do prédio, já estávamos na gestão de Michel Temer. Nesse momento, Rodrigo Maia pediu para ver o processo e parou tudo. Aí, uma outra deputada, que atua com ele, está pedindo para a Ação da Cidadania ficar no prédio.

Com isso, o Iphan entrou na justiça pedindo a reintegração de posse. Várias audiências públicas foram então promovidas na Câmara Municipal, na Assembleia Legislativa, e duas na Procuradoria da República no Rio de Janeiro, ${ }^{18}$ destinadas a analisar o uso do imóvel. Numa delas, realizada na Alerj em 11 de agosto de 2017, o Iphan da gestão de Temer declarou publicamente que outorgava à Secretaria Municipal de Cultura a responsabilidade pela realização do museu. Com isso, o Iphan transferiu para o órgão municipal uma responsabilidade que deveria ser sua e que se comprometeu junto à Unesco a assumir.

Os defensores do Memorial da Diáspora Africana, os apoiadores do MEL e os integrantes da ONG recorreram ao Ministério da Cultura para tentar resolver o conflito. No entanto, o ministro da Cultura, Sérgio Sá Leitão, alega ter uma posição de conciliação das principais instituições envolvidas, mas suas falas e ações tendem a privilegiar a presença da ONG no local:

O Ministério da Cultura reconhece a relevância do trabalho desenvolvido pela Ação da Cidadania, fundada pelo sociólogo Hebert de Souza (o Betinho), que tanto admiramos. Da mesma maneira entendemos a dimensão histórica do Cais

18 “Cais do Valongo: Patrimônio Cultural da Humanidade: e agora?”, em 6 de setembro de 2017, e “Cais do Valongo: Patrimônio Cultural da Humanidade: o que foi feito?”, em 8 de agosto de 2018. 
do Valongo. Portanto, se conseguirmos resolver essa questão entre nós será um grande avanço para o País. (Sá Leitão..., 2017).

O pedido de compartilhamento do espaço partiu da própria secretária de Cultura que, percebendo a força política que a ONG estava adquirindo, ficou receosa de perder o direito de construir naquele espaço o museu. A possibilidade de que o prédio possa vir a ter um uso compartilhado deixou indignados os integrantes dos movimentos negros. Numa outra audiência, o ministro da Cultura também recebeu de Milton Guran o abaixo-assinado para a criação do Museu Nacional do Valongo, o qual foi adotado por aclamação pela assembleia geral da Associação Nacional dos Professores Universitários de História, (Anphu), reunida em Brasília naquela ocasião, e escutou o seu apelo para que o museu se mantivesse sob a responsabilidade do Iphan - órgão vinculado ao Ministério da Cultura - mas não deu continuidade a essa proposta.

Para legitimar a sua permanência no prédio, a Ação da Cidadania desenvolveu o seu próprio projeto de criação de um museu afrodescendente e para tanto buscou apoio de alguns historiadores e intelectuais dedicados à história afro-brasileira. A ONG também circulou um abaixo-assinado na internet chamando o apoio e respeito à memória da organização e seus projetos sociais que teriam criado os alicerces para o Bolsa Família e para a seguridade social de milhões de brasileiros (A Ação..., 2017). Na mesma ocasião, um outro abaixo-assinado defendia a criação do Memorial da Diáspora Africana e a nacionalização do museu através do Iphan, e contava com a assinatura de reconhecidos pesquisadores ligados à história dos afrodescendentes e da escravidão. ${ }^{19}$ Os defensores do MEL, por sua vez, com o intuito de obter apoio para o seu projeto, convidam para as reuniões importantes personalidades do movimento negro, reconhecidas lideranças de religiões de matriz africana, renomados pesquisadores universitários e lideranças da região portuária.

19 Dentre eles o historiador Alberto da Costa e Silva (membro da Academia Brasileira de Letras e do Instituto Histórico e Geográfico Brasileiro), a professora Ana Lucia Araújo (Howard University), a pesquisadora Elisa Larkin Nascimento (Instituto de Pesquisas e Estudos Afro-Brasileiros), o professor João José Reis (Universidade Federal da Bahia), o cientista político e historiador José Murilo de Carvalho (Universidade Federal do Rio de Janeiro), o professor congolês Kabengele Munanga (Universidade de São Paulo), a professora Lilia Moritz Schwarcz (Universidade de São Paulo), o professor Paulo Knauss de Mendonça (Universidade Federal Fluminense) e o professor Rafael Sanzio Araújo dos Anjos (Universidade de Brasília). 
Tanto os defensores do MEL quanto os do Memorial da Diáspora Africana acusam a ONG de há muito ter se desvirtuado do seu papel inicial e, com o intuito de obter recursos financeiros, alugar o espaço para a realização de grandes eventos que contam com milhares de participantes. Segundo eles, essas festas contribuem para a deterioração do Cais do Valongo, já que seus frequentadores jogam latas de cerveja e urinam no mesmo. Além disso, as festas promoveriam o desrespeito ao simbolismo emanado pelo sitio arqueológico, reconhecido pela Unesco por evocar uma das maiores tragédias que se abateram sobre a humanidade.

De acordo com os critérios determinados pelo dossiê de candidatura do cais, e em comum acordo com a Unesco, o Iphan é o órgão responsável pela sua manutenção. Cabe a ele fiscalizar o bem tombado e implementar políticas gerais. Já a prefeitura, nesse mesmo termo de compromisso, assinado já na gestão de Marcelo Crivella, seria responsável pela segurança, manutenção, fiscalização, sinalização, iluminação, acolhimento dos turistas e visitantes, mas até o presente momento só se percebem os sintomas da falta do cuidado da prefeitura com o bem tombado. Não há iluminação noturna e nem acolhimento específico aos turistas, apesar das visitas diárias ao sítio. Alguns informantes manifestaram preocupação com o fato de o local ter se tornado ponto de moradores de rua e usuários de crack que ali mesmo evacuam e jogam lixo. Eles também se queixaram das práticas de skate no local e até de venda das pedras do cais aos turistas como suvenir.

O conflito em torno do prédio simboliza as diferenças entre as gestões municipais de Paes e Crivella. Para o primeiro, devido à importância do cais e do diálogo transnacional que o gerou, a sua gestão teria de ser de responsabilidade do governo federal, através do Iphan. A esse respeito, Milton Guran insiste que o compromisso com a Unesco é uma questão de ordem nacional e que o dever de memória em relação ao tráfico transatlântico é um assunto de Estado:

O Estado brasileiro deve à matriz africana um museu nacional que reconte a história do tráfico de escravos e dos africanos escravizados no Brasil e nas Américas, para dar visibilidade às suas realizações e estabelecer um diálogo efetivo com os demais países envolvidos com a Diáspora Africana nas Américas e na África.

Se o projeto defendido por Nilcemar Nogueira lhe outorga o mérito de ser a única pessoa do poder executivo a tomar as rédeas do museu na atualidade, podemos inverter a reflexão e afirmar que o fato dela se reivindicar como a 
principal responsável pela execução do mesmo desincumbiu o governo federal dessa responsabilidade.

Tanto o Memorial da Diáspora Africana quanto o MEL esbarram nas ações que, ao apoiarem a permanência da ONG no prédio, enfraquecem ou mesmo inviabilizam a própria realização do museu. Nesse caso, temos Rodrigo Maia, deputado federal pelo DEM e atual presidente da Câmara de Deputados, e o atual ministro da Cultura, para quem a construção do museu, a condenação da escravidão que ele evoca e o projeto de nação que ele implica não parecem estar entre as prioridades a serem defendidas pelo Estado, já que tudo indica que os seus principais esforços se concentram em garantir a permanência da ONG no local. Temos ainda setores do Estado, em nível tanto municipal quanto federal, que se desincumbem de suas responsabilidades em relação ao Cais do Valongo. Para estes, os significados emanados pelo cais e pelo MEL também não parecem ser prioritários. Temos, portanto, uma situação em que o projeto de criação do museu parece ser dificultado a partir de dentro de importantes órgãos do Estado.

Após vários embates, o Ministério Público Federal determinou em julho de 2018 a desocupação da ONG do local, assim como a transferência do imóvel da Secretaria do Patrimônio da União (SPU) para o Ministério da Cultura para a implantação de um Centro de Interpretação e de Celebração da Herança Africana, visando atender a exigência da Unesco para que o cais conservasse o título de patrimônio mundial. Tal decisão contrariou o processo anterior de transferência da gestão do prédio para o Iphan - responsável junto à Unesco pela elaboração do museu - e atribui amplos poderes ao atual ministro da Cultura, que se coloca explicitamente favorável à permanência da ONG no local, mesmo à revelia da decisão judicial. No dossiê que integra a candidatura a patrimônio mundial, consta que "é compromisso da Prefeitura do Rio de Janeiro e do IPHAN a implantação de um Memorial de Visitação, conforme previsto na já citada carta Recomendações do Valongo" (Sítio..., 2016, p. 169). Este memorial centralizaria as informações para o visitante e seria responsável pela exposição de parte do acervo arqueológico encontrado nas escavações. Em audiência pública de 8 de agosto de 2018, o ministro declarou que destinaria 2 milhões de reais para a criação do Centro de Interpretação, Referência e Visitação do Cais do Valongo e se mostrou favorável à presença da ONG no local até que as obras para o centro de referência sejam concluídas, por entender que a desocupação do prédio pode favorecer a depredação e/ou a ocupação por grupos criminosos. 
Ao mesmo tempo, o Ministério da Cultura desobrigou-se em relação ao projeto de um museu - seja ele da escravidão ou da diáspora africana - que seria muito mais oneroso e não estaria no seu escopo de ações. O ministro da Cultura, Sá Leitão, se comprometera a lançar em agosto de 2018 um edital com chamada pública para projetos de criação do Centro de Interpretação, Referência e Visitação do Cais do Valongo. Caberia à Fundação Cultural Palmeares, vinculada ao Ministério da Cultura, escolher o projeto, mas até meados de setembro isso não havia ocorrido. Através dessas ações, o ministro parece passar por cima dos projetos do MEL e do Memorial da Diáspora Africana e dos seus principais articuladores, projetando-os para um futuro incerto e duvidoso, para apenas dar cumprimentos às exigências da Unesco e garantir o título. De acordo com Milton Guran, temos assim uma total inversão de valores: o Ministério de Cultura se ocuparia do centro de interpretação e recepção de visitantes, que seria responsabilidade da prefeitura, enquanto a SMC se propõe fazer um museu que seria responsabilidade do governo federal.

Por ora não temos como avaliar o quanto a presença da ONG durante a elaboração do centro de interpretação pode dificultar a sua implementação. Mas é importante lembrar que a própria ONG alega já possuir um projeto de criação de um centro de referências afrodiaspórico, e podemos aventar a possibilidade de ela concorrer e vencer o futuro edital destinado à implementação do Centro de Interpretação, Referência e Visitação do Cais do Valongo. Alguns atores se aventuram a especular que o Ministério de Cultura estaria fazendo um acordo para ceder uma parte do prédio à Ação da Cidadania. O edital ficaria sob a responsabilidade da Fundação Palmares, vinculada ao Ministério da Cultura.

Com nome provisório, sem financiamento claro, com um espaço de execução no cerne das disputas, um plano museográfico incerto e um conselho consultivo que serão definidos de forma participativa em futuro duvidoso, o alinhamento do MEL com os preceitos da Nova Museologia parece ser insuficiente para enfrentar as inúmeras controvérsias que o cercam. ${ }^{20}$

20 Em fins de 2018, o nome oficial do museu foi alterado definitivamente para Museu da História e da Cultura Afro-Brasileira (MUHCAB), tendo por base uma consulta popular. A alteração no nome, a dificuldade crescente na obtenção do espaço do prédio Docas Pedro II e na permanência de Nilcemar Nogueira no cargo de secretária municipal de Cultura nos indicam que o projeto original do MEL caminha de fato para se transformar num grande ritual abortivo. 


\section{O que os conflitos nos informam}

Em indagações anteriores sobre a patrimonialização do Cais do Valongo pela Unesco, Vassallo e Cicalo (2015) descreviam o processo que culminaria com o enquadramento das memórias da escravidão no espaço público da região portuária. Um ano e meio de administração de Crivella e de Temer foi suficiente para pôr em xeque a institucionalização das memórias afrodescendentes na cidade e no país. Se no nível global a nomeação do Cais do Valongo como Patrimônio da Humanidade colocou a região portuária no roteiro global de sítios históricos vinculados à escravidão, a falta de vontade política no nível nacional e as celeumas da política local têm sido gritantes ao ponto de evidenciar mais que o total descompasso entre as políticas globais da memória e as ações locais: elas apontam para um desprezo das autoridades brasileiras pelas demandas de cuidado e conservação das memórias negras e suas lutas conexas.

A crise econômica da cidade no pós-grandes eventos não basta para explicar o pouco caso que o museu sobre a escravidão e a diáspora africana vem recebendo. No atual contexto, os debates sobre um museu que aborde os efeitos do tráfico desumano de africanos expõem as fraturas mais agudas dadas pela guinada política conservadora que tomou conta simultaneamente da cidade e do país. Nesse novo panorama, acreditamos que a institucionalização da memória da diáspora africana não apenas não esteja consolidada como atravesse uma disputa visceral para sobreviver.

A sensação que paira é que ao longo de 2017 e 2018 a prefeitura de Crivella deu as costas ao setor cultural e foi especificamente reativa às questões da cultura afro-brasileira. Uma série de gestos de omissão e até de persecução explícita pode ser listada para dar conta da atitude da prefeitura, começando pela ausência do prefeito na festa de comemoração da inclusão do Cais do Valongo na lista dos patrimônios mundiais, a qual foi não apenas sentida, como sinalizava a concretização de uma pauta contrária à cultura afrodescendente. $\mathrm{Na}$ mesma época, o prefeito anunciou que cortaria à metade a subvenção concedida ao desfile das escolas de samba do Grupo Especial e do Grupo A. A prefeitura também cortou o apoio financeiro a manifestações tradicionais da cidade como o Trem do Samba e a Procissão de Iemanjá. Não é coincidência que essa sequência de reduções de custos atinja eventos de religiões de matriz africana, os quais vão contra valores da Igreja Universal do Reino de Deus. 2017 
também será lembrado, em particular, como ano das perseguições silenciosas aos ensaios do grupo de maracatu Tambores de Olokum, a rodas de samba em locais tradicionais como Pedra do Sal e Praça Tiradentes, e da falta de repasse de verba para o Instituto Pretos Novos. ${ }^{21}$ Pelo mesmo motivo, a Casa do Jongo teve que fechar as portas no início de $2018 .^{22}$

Para Ivanir dos Santos, líder religioso, é sintomático da administração Crivella a intensificação dos ataques aos terreiros de umbanda e candomblé perpetrados por traficantes evangélicos na região metropolitana do Rio de Janeiro, os quais teriam sido alavancados pela ascensão da Igreja Universal no poder municipal. “É inegável que há uma segregação cultural. Na concepção da Igreja Universal, sempre houve uma demonização das religiões africanas. ${ }^{23} \mathrm{~A}$ vitória de Crivella no Rio não é mais que a ponta de lança do projeto político da Igreja Universal. ${ }^{24}$

Se no âmbito local o clima político não se mostrou propício ao projeto do museu, o nível nacional não tem sido mais atuante, especialmente no que se refere a uma decisão peremptória a respeito do local do museu, quando urge o apoio do Estado a essas iniciativas para galvanizar a investigação e ajudar a informar o público sobre os crimes da escravidão. A tardança na decisão sobre o despejo da ONG e a permissão para permanecer até o inicio das obras não é mais que um sintoma da falta de compromisso do Estado brasileiro com as medidas que lhe cabem como guardião do Cais do Valongo. Sabe-se que com o reconhecimento dado pelo Comitê do Patrimônio Mundial, o Brasil assumiu a obrigação legal de criar um local que reconte a história do tráfico de pessoas escravizadas - a criação do Memorial da Diáspora Africana é condição obrigatória para a manutenção do título da Unesco. No entanto, a gestão do Iphan sob a

21 Tanto a Pedra do Sal quanto o Instituto dos Pretos Novos se localizam nas imediações do Cais do Valongo. A primeira encarna o local mítico onde o samba teria surgido e o segundo foi criado sobre o cemitério de mesmo nome, que teria recebido os corpos de cerca de 30 mil africanos recém-desembarcados do tráfico, na virada do século XVIII para o XIX.

22 Localizada na favela da Serrinha e criada na gestão de Paes.

23 Fala de Ivanir dos Santos em 16/05/2017 no debate promovido pelo programa de História Comparada sobre o MEL, no (Instituto de Filosofia e Ciências Sociais/UFRJ.

24 As igrejas evangélicas vêm expandindo-se no Brasil a passos agigantados, não apenas em número de fiéis e templos, mas especialmente na política. Seus pastores tinham se concentrado inicialmente no poder Legislativo, mas, com as eleições de 2018, que resultaram na eleição de Jair Bolsonaro, podemos afirmar que evangélicos conquistaram seu lugar no poder Executivo. 
administração de Temer parece ter se desinteressado e se desincumbido dessa função, transferindo as suas obrigações para uma secretaria sem força política, com escassos recursos e pouco apoio popular. Acreditamos que a transferência de responsabilidade do órgão federal para o municipal reflita não um voto de confiança na secretária de Cultura, mas sim um desejo de silenciamento do debate que o cais e o museu suscitam. Trata-se de uma maneira de esvaziar um projeto político que já não interessa mais ao novo governo federal e de calar o protagonismo brasileiro em torno da escravidão em nível internacional, legitimado pelo reconhecimento do Cais do Valongo pela Unesco. Fica também a questão, muito bem colocada por um dos participantes desse processo: "Quem acredita que o Crivella vai fazer um museu para empoderar a matriz africana nessa cidade?"25

Há ainda a atuação do Ministério da Cultura dificultando a criação do museu. De acordo com Milton Guran, "eles preferem ter o apoio da ONG a ver aquele local nas mãos da matriz africana empoderada. Eu não sei quais são os motivos de fundo, o que eu sei é que eles estão barrando, estão atrapalhando aquilo ali". Para ele,

quando o Temer entrou, a candidatura já era irreversível. [No entanto], o governo Temer não quer valorizar a herança africana. Eles não puderam deixar de levar a termo a candidatura. Mas eles vão fazer tudo para esvaziar a candidatura, eles não vão usar esse título para valorizar a matriz africana, para colocar o Estado brasileiro como protagonista de primeira grandeza na discussão no mundo todo, eles não vão criar o museu, não vão fazer nada. É igual ao prefeito, ele não tem interesse, não vai fazer nada para ajudar e vai fazer tudo para atrapalhar.

De fato, o plano nacional nos aponta para um novo governo sem nenhuma sensibilidade para ações em prol da reflexão sobre a desigualdade racial. Quando as velhas oligarquias retomam o poder ansiando por velhas estruturas retocadas pelos interesses neoliberais, praticamente nenhum apoio a qualquer

25 A resposta já é dada pela atitude diferenciada do prefeito com relação ao Memorial do Holocausto no morro do Pasmado. Ele defende sua criação a capa e espada e arrecada ele próprio recursos, mesmo com o parecer contrário do Iphan. Um fato que merece uma análise que excede os limites desta reflexão. 
ação simbólica sobre a escravidão poderia ser esperado. É todo o contrário que parece ocorrer, se considerarmos que o governo de Michel Temer esteve disposto a negociar a recomposição da base aliada prometendo a flexibilização do trabalho escravo para agradar a bancada ruralista da Câmara de Deputados. Uma portaria que tentava dificultar as regras para combater o trabalho escravo é o maior exemplo da falta de sintonia que um museu sobre a escravidão poderia vir a obter por parte da união.

Sabemos do pouco efeito que os pedidos de desculpas podem trazer (Trouillot, 2000), porém a banalização da escravidão nas vozes dos políticos potencializa seus nefastos efeitos, perpetuando e legitimando atos de discriminação. Assim, um dos maiores efeitos do anúncio da desastrosa e desumana portaria do trabalho escravo foi tornar a ideia de trabalho escravo algo fútil. Mesmo que não venha a se consolidar, porque é contestada por diferentes setores, ela abre um precedente. Não foi um acaso que nesse mesmo ano Brasília tenha testemunhado episódios que relatam a total banalização da escravidão. Em primeiro lugar, vimos como o ministro do STF, Gilmar Mendes, debochou da escravidão dizendo que seu trabalho é exaustivo, mas não se considera escravo. Poucas semanas depois, a então ministra dos Direitos Humanos, Luislinda Valois (PSDB), negra, com vencimentos superiores a R\$ 30 mil, considerou seu trabalho análogo à escravidão, por não poder somar as rendas de desembargadora e ministra. Tais eventos foram divulgados e ironizados pela grande imprensa justamente no mês da Consciência Negra, esvaziando o conteúdo político das lutas dos militantes negros contra a desigualdade racial estrutural.

Estaríamos assistindo a uma operação de silenciamento do passado? Não o descartemos. Segundo Trouillot (2017), o silenciamento pode acontecer de duas formas distintas: a primeira consiste em promover generalizações de forma a apagar diretamente determinados eventos; a segunda, em esvaziar eventos singulares de seu conteúdo, normalmente por meio de um detalhamento feito de modo a banalizar toda uma cadeia de fatos.

Assim, compreende-se o mal-estar geral com que foi recebido o nome inicial proposto para o museu pela secretária de Cultura: mais que nominal, o incômodo é gerado pelas diversas formas de atualização da escravidão no momento atual. O que é insultante não é a presença do presente projetada no passado, mas a falsidade dessa relação com o que acontece no presente. Se a escravidão terminou oficialmente, ela certamente continua presente no racismo 
institucionalizado e nas formas de desqualificação da população afrodescendente. Daí a análise de Trouillot (2000) sobre a irreversibilidade das velhas feridas e seu ceticismo sobre a possibilidade real de qualquer reparação centrada apenas na publicização das memórias do passado.

Refletindo sobre a proliferação mundial de pedidos de desculpas que se exigem cada vez mais, Trouillot (2000) examina como esse tipo de gesto, que em nada modifica as estruturas de poder no presente, está condenado a não ser mais que um ritual abortivo no qual as suas próprias condições de emergência negam a possibilidade de transformação de um futuro comum e desejável para os descendentes das vítimas e dos perpetradores. $\mathrm{O}$ atual panorama brasileiro constitui-se em mais um exemplo da desconfiança que Trouillot tem manifestado em relação aos revisionismos sobre o passado, pois sem nenhum compromisso real com o presente qualquer representação da escravidão estará fadada a se converter num espetáculo falso e moralmente repugnante. A revisão da história do Brasil como a maior nação escravocrata do mundo, bem como as demandas por reparação que nela se ancoram, estão sendo silenciadas pelo poder público em seus diferentes níveis, transformando o MEL num ritual abortivo.

\section{Conclusão}

Neste artigo, sugerimos que o projeto do MEL encontra-se no cerne de tensões políticas muito mais amplas, daí a grande dificuldade da sua implementação. Os conflitos que o perpassam são reflexos de embates políticos travados numa esfera mais abrangente, o que deixa o projeto do museu tão fragilizado que corre o risco de sucumbir antes mesmo de vir à tona. Nesse sentido, procuramos analisar as principais tensões que o atravessam e refletir sobre o que elas nos informam.

Por um lado, o MEL atualiza as tensões entre as memórias da escravidão e da herança africana e traz à tona os fantasmas gerados pelas aviltantes representações públicas dos escravizados, gerando resistência por parte significativa dos ativistas negros e contribuindo para o isolamento da secretária de Cultura. Por outro, o museu estaria relacionado a um projeto de nação que reconhece a importância dos africanos e seus descendentes na sua construção e a sua dívida para com os mesmos, mas que parece ser contrário aos interesses dos 
setores que assumiram o poder tanto no município quanto no governo federal. Por isso ele não tem mais o suporte do Estado, ou ao menos dos órgãos centrais à sua realização. Assim, enquanto o governo delega a sua responsabilidade, 0 projeto do MEL se enfraquece, a secretária de Cultura se isola e a "verdade" do museu é silenciada antes mesmo de ser formulada. O projeto do MEL gira em círculos, cada vez mais agonizante.

Acima de tudo, o MEL expressa os limites e os paradoxos do regime presentista e expõe a ambiguidade e as tensões de um projeto de musealização da escravidão num contexto de recrudescimento das históricas políticas de exclusão dos afrodescendentes que ocorre atualmente no plano municipal e federal:

Mas o presentismo é por definição anacrônico. Condenar só a escravidão é a saída fácil [...]. O que se necessita denunciar aqui para restaurar a autenticidade não é tanto a escravidão, mas sim o presente racista dentro do qual as representações da escravidão são produzidas. A incongruência moral provém deste incômodo solapamento das duas caras da historicidade. (Trouillot, 2017, p. 129, tradução nossa).

\section{Referências}

A AÇÃO da Cidadania sob ataque. 12 maio 2017. Disponível em: http://www.acaodacidadania.com.br/?page=noticias\&id=375. Acesso em: 12 maio 2017.

ALMEIDA, R. de. A onda quebrada. Evangélicos e conservadorismo. Cadernos Pagu, n. 50, 2017a, el75001.

ALMEIDA, R. de. Os deuses do parlamento. Novos Estudos Cebrap, São Paulo, n. esp., p. 71-79, jun. 2017b.

ARAUJO, A. L. Mémoires de l'esclavage et de la traite des esclaves dans l'Atlantique Sud: enjeux de la patrimonialisation au Brésil et au Bénin. 2007. Thèse ( $\mathrm{PhD}$ en Histoire)

- Faculté des Lettres, Université Laval, Québec, 2007.

ARAUJO, A. L. Shadows of the slave past: memory, slavery and history. New York: Routledge, 2014.

BARRETT, A. R. D. Honoring the ancestors: historical reclamation and self determined identities in Richmond and Rio de Janeiro. 2014. Dissertation (PhD in Anthropology) Department of Anthropology, College of William and Mary, Williamsburg, 2014. 
BLAKEY, M. Le projet de cimetière africain: un paradigme pour la coopération?. Museum, v. 62, n. 245-246, p. 64-71, 2010.

BRUNER, E. M. Culture on tour: ethnographies of travel. Chicago, The University of Chicago Press, 2004.

CHIVALLON, C. Bristol and the eruption of memory: making the slave trading past visible. Social and Cultural Geography, v. 2, n. 3, p. 347-363, 2001.

CHIVALLON, C. L'esclavage, du souvenir à la mémoire. Paris: Karthala: CIRESC, 2012.

CIARCIA, G. Mémoire de l'esclave au Bénin: le passé à venir. Gradhiva, n. 8, p. 4-9, 2008. Disponível em: http://gradhiva.revues.org/1161. Acesso em: 1 dez. 2017.

CONFERÊNCIA Mundial contra o Racismo, Discriminação Racial, Xenofobia e Intolerância Correlata. Durban, 2001. Disponível em: http://www.unfpa.org.br/Arquivos/ declaracao_durban.pdf. Acesso em: 2 ago. 2017.

DUFFY, T. M. Museums of 'human suffering' and the struggle for human rights. Museum International, Paris, v. 53, n. 1, p. 11-16, 2001.

FASSIN, D. Ce qui s'est vraiment passé: l'experience du musée de l'Apartheid. Gradhiva, n. 5, p. 52-61, 2007. Disponível em: http://gradhiva.revues.org/724. Acesso em: 1 dez. 2017.

FASSIN, D.; RECHTMAN, R. L'empire du traumatisme: enquête sur la condition de victime. Paris: Flammarion, 2011.

GOIS, A. Após dizer que queria criar Museu da Escravidão, Crivella destina só R\$ 1 mil ao projeto. O Globo, 28 jan. 2018. Disponível em: http://blogs.oglobo.globo.com/ ancelmo/post/apos-dizer-que-queria-criar-museu-da-escravidao-crivella-destina-so-r-1-mil-ao-projeto.html. Acesso em: 28 jan. 2018.

GUIMARÃES, R. S. Patrimônios e conflitos de um afoxé na reurbanização da região portuária carioca. Mana, Rio de Janeiro, v. 22, n. 2, p. 311-340, 2016.

HARRINGTON, S. P. M. Bones and bureaucrats? New York's great cemetery imbroglio. Archeology, p. 29-38, March/April 1993.

HARTOG, F. Regimes de historicidade: presentismo e experiências do tempo. Belo Horizonte: Autêntica, 2013.

HAYDEN, D. The power of place: urban landscapes as public history. Cambridge: The MIT Press, 1997.

HISTORIADORES dos EUA dizem que Portugal deve desculpas por tráfico de escravos. 17 jul. 2017. Disponível em: http://agenciabrasil.ebc.com.br/internacional/ noticia/2017-07/historiadores-dos-eua-dizem-que-portugal-deve-desculpas-por-trafico-de. Acesso em: 10 out. 2017. 
HUYSSEN, A. Seduzidos pela memória: arquitetura, monumentos, mídia. Rio de Janeiro: Aeroplano, 2000.

KAUFMAN, N. Place, race and story: essays on the past and future of historic presevation. New York: Routledge 2009.

LISBOA, V. Futuro Museu da Escravidão e da Liberdade recebe primeiro objeto do acervo. 21 mar. 2017. Disponível em: http://agenciabrasil.ebc.com.br/cultura/noticia/2017-03/ futuro-museu-da-escravidao-e-da-liberdade-recebe-primeiro-objeto-do-acervo. Acesso em: 28 jan. 2018.

LOPES, N. Mel amargo. O Globo, 13 jun. 2017. Disponível em: https://oglobo.globo. com/opiniao/mel-amargo-21469991. Acesso em: 28 jan. 2018.

LOWENTHAL, D. On arraigning ancestors: a critique of historical contrition. North Carolina Law Review, v. 87, n. 3, p. 901-966, 2009.

MARTIN M. T.; YAQUINTO M. Reparations for 'America's Holocaust': activism for global justice. Race and Class, v. 45, n. 4, p. 1-25, 2004.

MUSEU de Escravidão e da Liberdade: discurso de posse. 21 mar. 2017. Disponível em: http://tour.rio/web/smc/exibeconteudo?id=6833141. Acesso em: 16 dez. 2017.

NOGUEIRA, N. Por um museu sobre a verdade. O Globo, 22 jan. 2017. Disponível em: https://oglobo.globo.com/opiniao/por-um-museu-sobre-verdade-20806072. Acesso em: 28 jan. 2018.

REIS, L. F.; AUTRAN, P. Secretária municipal de Cultura mira ISS e pede criatividade dos gestores. O Globo, 2 jan. 2018. Disponível em: https://oglobo.globo.com/cultura/ secretaria-municipal-de-cultura-mira-iss-pede-criatividade-dos-gestores-22245463. Acesso em: 28 jan. 2018.

RELATÓRIO parcial da Comissão Estadual da Verdade da Escravidão Negra no Brasil, OAB RJ. Rio de Janeiro, 2015.

RIO DE JANEIRO (Município). Decreto $n^{\circ} 43.128$, de 12 de maio de 2017. Cria o Museu da Escravidão e da Liberdade - MEL, no bem cultural que menciona e dá outras providências. Rio de Janeiro, 2017. Disponível em: https://leismunicipais.com.br/al/ rj/r/rio-de-janeiro/decreto/2017/4313/43128/decreto-n-43128-2017-cria-o-museu-da-escravidao-e-da-liberdade-mel-no-bem-cultural-que-menciona-e-da-outras-providencias?q=43128. Acesso em: 28 jan. 2018.

RIO DE JANEIRO (Município). Projeto de lei $n^{\circ} 774 / 2018$. Estabelece normas, como exigência de reparação pelos crimes de escravidão, a demarcação da área urbana como território histórico para preservação de memória da presença do africano liberto e alforriado e seu local de trabalho e moradia na cidade do Rio de Janeiro. Rio de Janeiro, 2018. 
SÁ LEITÃO coordena reunião sobre cessão de prédio que deve abrigar Museu da Diáspora Africana, no Rio. 11 ago. 2017. Disponível em: http://www.cultura.gov. br/o-dia-do-ministro/-/asset_publisher/RUSw3TZhXdVb/content/sa-leitao-coordena-reuniao-sobre-cessao-de-predio-que-deve-abrigar-museu-da-diaspora-africana-no-rio/10883. Acesso em: $18 \mathrm{dez} .2017$.

SANTOS, M. S. dos. Representations of black people in Brazilian museums. Museum and Society, v. 3, n. 1, p. 51-65, Mar. 2005.

SANTOS, M. S. dos. The legacy of slavery in contemporary Brazil. In: ARAUJO, A. L. (ed.). African heritage and memories of slavery in Brazil and the South Atlantic world. Amherst: Cambria Press, 2015. p. 313-339.

SARTI, C. A vítima como figura contemporânea. Cadernos $C R H$, Salvador, v. 24, n. 61, p. 51-61, jan./abr. 2011.

SÍTIO arqueológico Cais do Valongo: proposta de inscrição na lista do patrimônio mundial. Rio de Janeiro, 2016. Disponível em: http://portal.iphan.gov.br/uploads/ publicacao/valongo4_07mai_web.pdf. Acesso em: 28 jan. 2018.

SMITH, L. et al. (ed.). Representing enslavement and abolition in museums: ambiguous engagements. London: Routledge, 2011.

TROUILLOT, M.-R. Abortive rituals: historical apologies in the Global Era. Interventions, v. 2, n. 2, p. 171-186, 2000.

TROUILLOT, M.-R. Silenciando el pasado: el poder y la producción de la historia. Granada: Editorial Comares, 2017.

VASSALLO, S. P. Interventions urbaines et processus de patrimonialisation: la construction d'un territoire noir dans la zone portuaire de Rio de Janeiro (1980-2000). In: CAPONE, S.; MORAES, M. R. de. (dir.). Afro-patrimoines: culture afro-brésilienne et dynamiques patrimoniales. Paris: Lahic: DPRPS, 2015. p. 139-161.

VASSALLO, S. P.; CICALO, A. Por onde os africanos chegaram: o Cais do Valongo e a institucionalização da memória do tráfico negreiro na região portuária do Rio de Janeiro. Horizontes Antropológicos, Porto Alegre, ano 21, n. 43, p. 239-271, 2015.

Recebido: 31/01/2018 Aceito: 29/11/2018 | Received: 1/31/2018 Accepted: 11/29/2018 